\title{
Experimental Performance Evaluation of a Photovoltaic Thermal (PV/T) Air Collector and Its Optimization
}

\author{
Mohsen Mahdavi Adeli ${ }^{1}$ - Fatemeh Sobhnamayan² - Said Farahat ${ }^{3}$ - Mahmood Abolhasan Alavi² - \\ Faramarz Sarhaddi*,3 \\ 1Department of Mechanical Engineering, Susangerd Branch, Islamic Azad University, Susangerd, Iran \\ 2Department of Mechanical Engineering, Mashhad Branch, Islamic Azad University, Mashhad, Iran \\ 3Department of Mechanical Engineering, University of Sistan \& Baluchestan, Zahedan, Iran
}

\begin{abstract}
The aim of the present study is the simultaneous optimization of thermal and electrical efficiencies of a solar photovoltaic thermal (PV/T) air collector. The analytical expressions for thermal parameters and thermal efficiency are derived by developing energy balance equation for each component of PV/T air collector. In order to calculate the electrical parameters and electrical efficiency of PV/T air collector the five-parameter current-voltage (I-V) model and a set of translation equations are used. An experimental setup for a typical PV/T air collector is built to measure its thermal and electrical parameters. The experimental validation of the used thermal and electrical models has been carried out by the measured data. It is observed that there is a good agreement between simulated and experimental results. Finally, the simultaneous optimization of the PV/T air collector has been carried out to maximize thermal and electrical efficiencies, simultaneously. Furthermore, the optimized ranges of inlet air velocity, duct depth and the objective functions in optimal Pareto front have been obtained.
\end{abstract}

Keywords: solar photovoltaic thermal (PV/T) air collector, simultaneous optimization

\section{O INTRODUCTION}

PV systems are one of the main substitutes for fossil fuels since they exhibit many merits such as cleanness, little maintenance and no noise. However, they still present a vast area of competition comparing to conventional energy resources due to their high cost and low efficiency during energy conversion. The electrical efficiency of a PV system is highly dependent on its surface temperature. If the surface temperature of PV system is reduced its electrical efficiency is increased. In order to increase the electrical efficiency of PV system and reduce its energy payback time (EPBT), it is combined with the solar air/water heater collector. This type of a system is called solar photovoltaic thermal $(\mathrm{PV} / \mathrm{T})$ collector. The PV/T collector produces thermal and electrical energy simultaneously.

A significant amount of theoretical as well as experimental studies on the $\mathrm{PV} / \mathrm{T}$ systems has been carried out in the last 40 years. Wolf [1] was the first to give the main concept of $\mathrm{PV} / \mathrm{T}$ collector using water or air as the working fluid. Bhargava et al. [2] have analyzed a hybrid system which is a combination of an air heater and PV system parameters such as channel depth, length of the collector, and air mass flow rate. Hagazy [3] has investigated glazed PV/T air system for a single and double pass air heater for space heating and the drying purposes. Infield et al. [4] have suggested reducing the temperature of the PV module by flowing air between the PV module and the double glass wall for space heating. They have developed a steady-state model to evaluate an overall heat loss coefficient and thermal gain factor. Tiwari et al. [5] have validated the theoretical and experimental results for the PV module integrated with air duct for composite climate of India and concluded that an overall thermal efficiency of $\mathrm{PV} / \mathrm{T}$ system is significantly increased (18\%) due to utilization of thermal energy from PV module. Dubey et al. [6] have derived the expression for temperature dependent electrical efficiency considering glass to glass and glass to tedlar type PV modules. Joshi et al. [7] have compared thermal performance of a glassto-tedlar $\mathrm{PV} / \mathrm{T}$ air collector and a glass-to-glass $\mathrm{PV} / \mathrm{T}$ air collector and concluded that the glass-to-glass $\mathrm{PV} / \mathrm{T}$ air collector has a better thermal performance than a glass-to-tedlar PV/T air collector. Tiwari and coworkers [8] and [9] have presented a numerical model predicting the performance of $\mathrm{PV} / \mathrm{T}$ system, and experimentally validated for various configurations. The exergy analysis and exergetic optimization of PV modules have been carried out by Sarhaddi et al. [10] and [11]. They have indicated that the exergy efficiency of the PV array may be improved if heat can be removed from the PV array surface. Kim et al. [12] have investigated the effect of ambient temperature on the thermal characteristics of a PV module with and without fins and concluded that the surface temperature of PV module with fins is lesser than the one without fins because heat is emitted at the fins. Agrawal and Tiwari [13] have evaluated the 
energy and exergy performance of a micro-channel photovoltaic thermal (MCPVT) collector under the constant mass flow rate of air. Their numerical computations have shown that the energy and exergy yields of a MCPVT collector are higher than the yields of conventional $\mathrm{PV} / \mathrm{T}$ air collectors.

The PV/T system produces useful heat and electricity simultaneously and its performance is determined by thermal and electrical efficiencies. An increase in the electrical efficiency of PV/T system causes a decrease in its thermal efficiency and vice versa. In previous studies [1] to [13], the simultaneous optimization of the thermal and electrical efficiencies of $\mathrm{PV} / \mathrm{T}$ air collector was not carried out. In this paper, a multi-objective optimization is develoved to maximize the thermal efficiency and electrical efficiency of PV/T air collector at the same time. The simultaneous optimization of $\mathrm{PV} / \mathrm{T}$ system is parametrically dependent on its thermal and electrical analysis. Hence, in the next sections these analyses will be carried out.

\section{THERMAL ANALYSIS}

The proof of governing equations on the thermal analysis of $\mathrm{PV} / \mathrm{T}$ air collector is not included to have a brief note. More details of the governing equations derivation is found in [5] to [9].

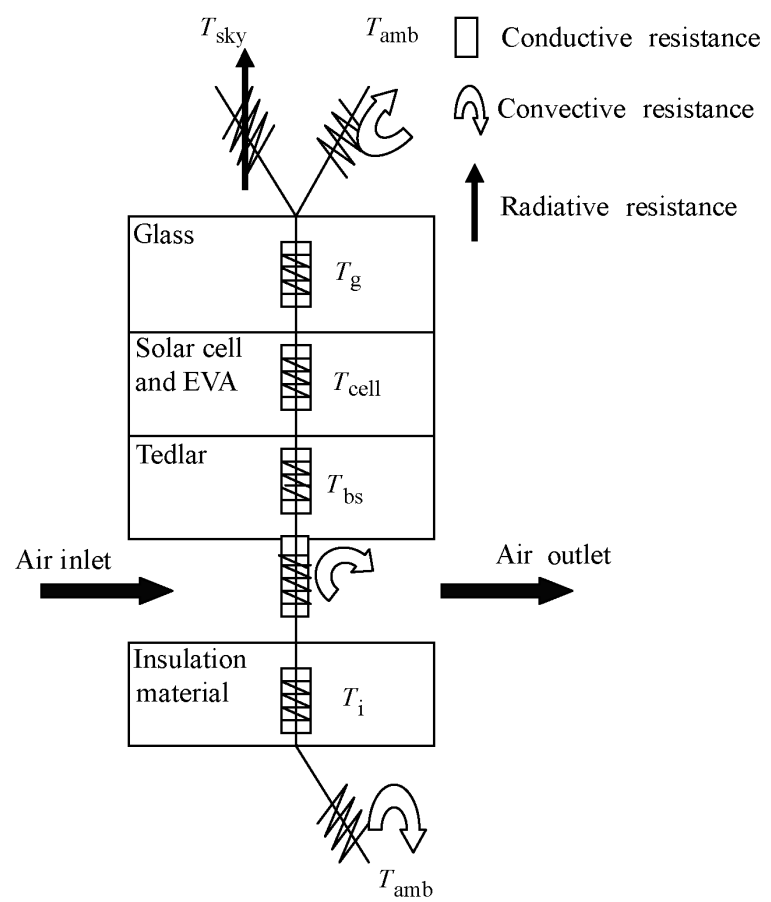

Fig. 1. The equivalent thermal resistant circuit of a PV/T air collector [5] to [9]
The analytical expressions for the thermal parameters and thermal efficiency of PV/T air collector can be obtained if the energy balance equation is written for each components of $\mathrm{PV} / \mathrm{T}$ air collector. Fig. 1 shows the equivalent thermal resistant circuit of a PV/T air collector.

$$
\begin{gathered}
T_{\text {cell }}=\left((\alpha \tau)_{e f f} G+U_{t} T_{a m b}+U_{T} T_{b s}\right) /\left(U_{t}+U_{T}\right), \\
T_{b s}=\left(h_{p 1}(\alpha \tau)_{e f f} G+U_{t T} T_{a m b}+h_{f} T_{f}\right) /\left(U_{t T}+h_{f}\right), \\
T_{f, \text { out }}=\left(T_{a m b}+\frac{h_{p 1} h_{p 2}(\alpha \tau)_{e f f} G}{U_{L}}\right) . \\
\cdot\left(1-\exp \left(\frac{-W U_{L} L}{\dot{m} C_{p}}\right)\right)+T_{f, \text { in }} \exp \left(\frac{-W U_{L} L}{\dot{m} C_{p}}\right), \\
\dot{Q}_{u}=\dot{m} C_{p}\left(T_{f, \text { out }}-T_{f, \text { in }}\right)=\frac{\dot{m} C_{p}}{U_{L}}\left[h_{p 1} h_{p 2}(\alpha \tau)_{e f f} G-\right. \\
\left.-U_{L}\left(T_{f, \text { in }}-T_{a m b}\right)\right] \cdot\left[1-\exp \left(\frac{-W U_{L} L}{\dot{m} C_{p}}\right)\right], \\
\dot{m} C_{p}\left[h_{p 1} h_{p 2}(\alpha \tau)_{e f f}-\frac{U_{L}\left(T_{f, \text { in }}-T_{a m b}\right)}{G}\right] . \\
\left.\eta_{t h}\right) \\
\left.\qquad 1-\exp \left(\frac{-W U_{L} L}{\dot{m} C_{n}}\right)\right],
\end{gathered}
$$

where $T_{\text {cell }}, T_{b s}, T_{a m b}, T_{f}, T_{f, i n}, T_{f, \text { out }}, \dot{Q}_{u}, G, U_{L}$, $\dot{m}, C_{p},(\alpha \tau)_{e f f}, h_{p 1},, h_{p 2}, h_{f}, L, W$, and $\eta_{t h}$ are solar cell temperature, back surface temperature, ambient temperature, average air temperature, inlet air temperature, outlet air temperature, the rate of useful thermal energy, solar radiation intensity, overall heat loss coefficient, the mass flow rate of flowing air, the heat capacity of flowing air, the product of effective absorptivity and transmissivity, the penalty factor due to the presence of solar cell material, glass and EVA, the penalty factor due to the presence of interface between tedlar and working fluid, convective heat transfer coefficient in flow duct, the length of air duct, the width of air duct and PV/T air collector thermal efficiency, respectively.

\section{ELECTRICAL ANALYSIS}

In order to calculate the electrical parameters and electrical efficiency of PV/T air collector the fiveparameter current-voltage $(I-V)$ model (Fig. 2) are used as follows [14]. 


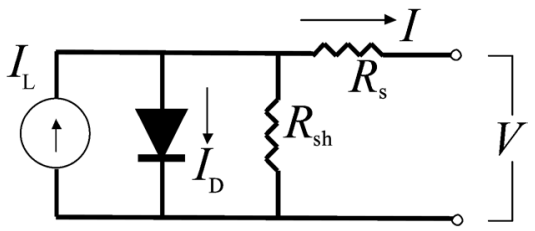

Fig. 2. Equivalent electrical circuit in the five-parameter photovoltaic model [14]

$$
I=I_{L}-I_{o}\left[\exp \left(\frac{\left(V+I R_{S}\right)}{a}\right)-1\right]-\frac{\left(V+I R_{S}\right)}{R_{s h}},
$$

where, $I$ and $V$ represent current and voltage at load, $a, I_{L}, I_{o}, R_{s}, R_{s h}$ are ideality factor, light current, diode reverse saturation current, series resistance and shunt resistance, respectively. In order to calculate five reference parameters $\left(a_{r e f,} I_{L, r e f,} I_{o, r e f,} R_{s, r e f,}\right.$ and $\left.R_{s h, r e f}\right)$, the five pieces of information are needed at reference conditions. These five pieces of information are defined as follows [14]:

- At short circuit current: $I=I_{s c, r e f}, V=0$.

- At open circuit voltage: $I=0, V=V_{o c, r e f}$.

- At the maximum power point:

$$
I=I_{m p, r e f}, V=V_{m p, r e f} \text {. }
$$

- At the maximum power point:

$$
\left[\frac{d(I V)}{d V}\right]_{m p}=\left[V \frac{d I}{d V}+I\right]_{m p}=0 .
$$

- At short circuit: $[d I / d V]_{s c}=-1 / R_{s h, r e f}$.

The subscript ref indicates the value of parameters at the reference conditions. Reference conditions or standard rating conditions (SRC) are defined as follows [14]:

- Solar cell temperature at reference conditions is $T_{\text {cell, ref }}=25^{\circ} \mathrm{C}$.

- The solar radiation intensity at reference conditions is $G_{r e f}=1000 \mathrm{~W} / \mathrm{m}^{2}$.

Substituting the mentioned five pieces of information into Eq. (6), the following equations are obtained:

$$
\begin{gathered}
F_{1}=-I_{s c, r e f}+I_{L, r e f}-I_{s c, r e f} R_{s, r e f} / R_{s h, r e f}- \\
-I_{o, r e f}\left[\exp \left(I_{s c, r e f} R_{s, r e f} / a_{r e f}\right)-1\right]=0, \\
F_{2}=I_{L, r e f}-I_{o, r e f}\left[\exp \left(V_{o c, r e f} / a_{r e f}\right)-1\right]- \\
-V_{o c, r e f} / R_{s h, r e f}=0, \\
F_{3}=-I_{m p, r e f}-I_{o, r e f}\left[\exp \left(\frac{V_{m p, r e f}+I_{m p, r e f} R_{s, r e f}}{a_{r e f}}\right)-1\right]+ \\
+I_{L, \text { ref }}-\left(V_{m p, r e f}+I_{m p, r e f} R_{s, r e f}\right) / R_{s h, r e f}=0,
\end{gathered}
$$

$$
F_{4}=V_{m p, r e f}\left[\frac{\frac{-I_{o, r e f} e^{\left(\frac{V_{m p, r e f}+I_{m p, r e f} R_{s, \text { ref }}}{a_{\text {ref }}}\right)}}{a_{\text {ref }}}-\frac{1}{R_{s h, r e f}}}{1+\frac{I_{o, r e f} e^{\left(\frac{V_{m p, r e f}+I_{m p, r e f} R_{s, r e f}}{a_{\text {ref }}}\right)}}{a_{\text {ref }}} R_{s, \text { ref }}+\frac{R_{s, \text { ref }}}{R_{\text {sh, ref }}}}\right]+
$$

$$
F_{5}=\left[\begin{array}{c}
\frac{-I_{o, r e f} e^{\left(\frac{I_{s c, r e f} R_{s, r e f}}{a_{r e f}}\right)}}{a_{r e f}}-\frac{1}{R_{s h, r e f}} \\
1+\frac{I_{o, r e f} e^{\left(\frac{I_{s c, r e f} R_{s, r e f}}{a_{r e f}}\right)}}{a_{r e f}} R_{s, r e f}+\frac{R_{s, r e f}}{R_{s h, r e f}}
\end{array}\right]+
$$

where $V_{o c}, V_{m p}, I_{s c}$ and $I_{m p}$ are open-circuit voltage, maximum power point voltage, short-circuit current and maximum power point current, respectively. Functions $F_{1}, F_{2}, F_{3}, F_{4}$ and $F_{5}$ form a set of five nonlinear equations in five unknown variables $x_{1}$ $=a_{r e f}, x_{2}=I_{L, r e f}, x_{3}=I_{o, r e f}, x_{4}=R_{s, \text { ref }}$ and $x_{5}=R_{s h, \text { ref. }}$. There is a solution for above set in the Type 94 of TRNSYS [6]. However, in this study the mentioned set is solved by iterative methods. Since the Eqs. (7) to (11) are implicit and nonlinear equations, the NewtonRaphson method is used to solve them [14]. The simultaneous equations set of the Newton Raphson method in matrix form is defined as follows:

$$
\left[\begin{array}{lllll}
\frac{\partial F_{1}}{\partial x_{1}} & \frac{\partial F_{1}}{\partial x_{2}} & \frac{\partial F_{1}}{\partial x_{3}} & \frac{\partial F_{1}}{\partial x_{4}} & \frac{\partial F_{1}}{\partial x_{5}} \\
\frac{\partial F_{2}}{\partial x_{1}} & \frac{\partial F_{2}}{\partial x_{2}} & \frac{\partial F_{2}}{\partial x_{3}} & \frac{\partial F_{2}}{\partial x_{4}} & \frac{\partial F_{2}}{\partial x_{5}} \\
\frac{\partial F_{3}}{\partial x_{1}} & \frac{\partial F_{3}}{\partial x_{2}} & \frac{\partial F_{3}}{\partial x_{3}} & \frac{\partial F_{3}}{\partial x_{4}} & \frac{\partial F_{3}}{\partial x_{5}} \\
\frac{\partial F_{4}}{\partial x_{1}} & \frac{\partial F_{4}}{\partial x_{2}} & \frac{\partial F_{4}}{\partial x_{3}} & \frac{\partial F_{4}}{\partial x_{4}} & \frac{\partial F_{4}}{\partial x_{5}} \\
\frac{\partial F_{5}}{\partial x_{1}} & \frac{\partial F_{5}}{\partial x_{2}} & \frac{\partial F_{5}}{\partial x_{3}} & \frac{\partial F_{5}}{\partial x_{4}} & \frac{\partial F_{5}}{\partial x_{5}}
\end{array}\right] \times\left[\begin{array}{l}
x_{1, t}-x_{1, c} \\
x_{2, t}-x_{2, c} \\
x_{3, t}-x_{3, c} \\
x_{4, t}-x_{4, c} \\
x_{5, t}-x_{5, c}
\end{array}\right]=\left[\begin{array}{c}
F_{1} \\
F_{2} \\
F_{3} \\
F_{4} \\
F_{5}
\end{array}\right],
$$

where subscripts $t$ and $c$ refer to temporary and correct values of unknown variables. Solving the equations set of the Newton Raphson method gives the value of five parameters $\left(a_{\text {ref, }} I_{L, \text { ref, }} I_{o, \text { ref, }} R_{s, \text { ref, }}\right.$ and $\left.R_{\text {sh, ref }}\right)$, at the reference conditions $\left(T_{\text {cell, ref }}=25^{\circ} \mathrm{C}, G_{\text {ref }}=1000\right.$ 
$\mathrm{W} / \mathrm{m}^{2}$ ). In order to calculate the model parameters at new climatic and operating conditions $\left(G_{\text {new }}, T_{\text {cell, new }}\right)$, a set of translation equations is used such as follows [14]:

$$
\begin{aligned}
& a / a_{\text {ref }}=T_{\text {cell }} / T_{\text {cell, ref }}, \\
& \frac{I_{o}}{I_{o, \text { ref }}}=\left(\frac{T_{\text {cell }}}{T_{\text {cell, ref }}}\right)^{3} \exp \left(\frac{\varepsilon N_{c}}{a_{\text {ref }}}\left(1-\frac{T_{\text {cell, ref }}}{T_{\text {cell }}}\right)\right) \text {, } \\
& I_{L}=\left(G / G_{r e f}\right)\left[I_{L, r e f}+\alpha\left(T_{\text {cell }}-T_{\text {cell, ref }}\right)\right] \text {, } \\
& \Delta T=T_{\text {cell }}-T_{\text {cell, ref }}, \\
& \Delta I=\alpha\left(G / G_{r e f}\right) \Delta T+\left(G / G_{r e f}-1\right) I_{s c, r e f}, \\
& \Delta V=\beta \Delta T-R_{s} \Delta I, \\
& I_{s c}=I_{s c, r e f}+\Delta I \text {, } \\
& V_{o c}=V_{o c, r e f}+\Delta V, \\
& R_{s}=\frac{\frac{\left(2 V_{m p}-V_{o c}\right) \ln \left(1-I_{m p} / I_{s c}\right)}{I_{m p} /\left(I_{s c}-I_{m p}\right)+\ln \left(1-I_{m p} / I_{s c}\right)}+V_{o c}-V_{m p}}{I_{m p}} \text {, } \\
& R_{s h}=\frac{I_{s c} R_{s}}{I_{L}-I_{o}\left[\exp \left(I_{s c} R_{s} / a\right)-1\right]-I_{s c}},
\end{aligned}
$$

where $\varepsilon, N_{c}, \alpha$ and $\beta$ are semiconductor band gap energy (1.12 eV for silicon solar cell), cells number in series, current temperature coefficient and voltage temperature coefficient, respectively. PV module manufacturers usually give temperature coefficients. The new value of $V_{m p}$ and $I_{m p}$ is obtained from the maximum area of rectangle under the $I-V$ characteristic curve, $[d(I V) / d V]_{m p}=0$, at new climatic and operating conditions. It is necessary to mention the equation $[d(I V) / d V]_{m p}=0$, (Eqs. (6), (20) and (21)) are constituted a set of implicit and nonlinear equations to update the value of $V_{m p}, I_{m p}, R_{s}$ and $R_{s h}$. This set of equations is solved by the NewtonRaphson method [14].

The consumed electrical power by fans to circulate working fluid in the $P V / T$ air collector is calculated from [15]:

$$
P_{\text {fan }}=\frac{1.2465 \times 10^{4} A_{P V / T} h_{f}^{3.5} \mu^{1.83} D_{h}^{0.5}}{k^{2.33} C_{p}^{1.17} \rho^{2} \eta_{f a n}},
$$

$$
D_{h}=\frac{4 \times \text { Cross }- \text { sectional area of duct }}{\text { Wetted perimeter }}=\frac{4 \delta W}{2(\delta+W)},
$$

The electrical efficiency of $P V / T$ air collector is defined as the ratio of actual electrical output power to input the rate of solar energy incident on the $P V / T$ surface as follows:

$$
\eta_{e l}=\frac{V_{m p} I_{m p}-P_{f a n}}{G A_{P V / T}} .
$$

In the previous equations, $D_{h}, A_{P V / T}, \delta, h_{f}, \mu, k$, $\rho$ and $\eta_{f a n}$ are hydraulic diameter of flow duct, $P V / T$ surface area, duct depth, the viscosity, conductivity, density of agent fluid and fan efficiency, respectively.

\section{FORMULATION OF OPTIMIZATION PROBLEM}

The formulation of simultaneous optimization problem is given as follows:

$$
\left\{\begin{array}{l}
\text { Maximize }:\left[\begin{array}{l}
\eta_{t h}=E q . \text { (5) } \\
\eta_{e l}=E q . \text { (24) }
\end{array}\right], \\
\text { subject to } \\
0.01 \leq \delta \leq 0.2 \mathrm{~m}, \\
0.01 \leq V_{i n} \leq 12 \mathrm{~m} / \mathrm{s}, \\
T_{c e l l}, T_{f, o u t}, T_{b s}, T_{f}, \dot{m}, C_{p}, I_{o}, I_{L}, R_{s}, R_{s h}, a, \\
I_{s c}, V_{o c}, I_{m p}, V_{m p}, U_{L}, U_{t}, U_{T}, U_{t T}, h_{f}, \dot{Q}_{u}, \\
D_{h}, \mu, \rho, k, P_{f a n},(\alpha \tau)_{e f f}, h_{p 1}, h_{p 2}, e t c . \geq 0 \\
\text { and } \\
\text { other nonlinear constraints [5] to [9]. }
\end{array}\right.
$$

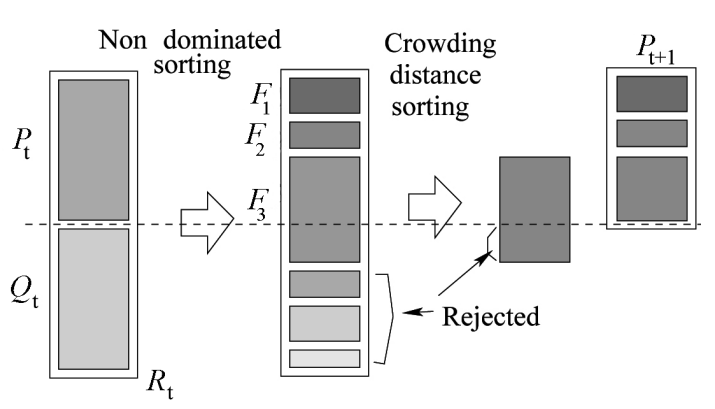

Fig. 3. A sketch of NSGA-Il algorithm [16]

The simultaneous optimization problem of the $P V / T$ colletor is a type of constraint multi-objective optimization problems. The objective functions and the constraint equations are nonlinear. Parameters 
$\delta$ and $V_{\text {in }}$ are independent variables in optimization problem. In order to solve the optimization problem, NSGA-II agorithm is used. A schematic sketch of NSGA-II algorithm is shown in Fig. 3 [16].

More details of the NSGA-II algorithm and its solution are found in Ref. [16].

\section{EXPERIMENTAL SETUP AND EXPERIMENTAL VALIDATION}

The experimental setup consists of one polycrystalline silicon PV module $(45 \mathrm{~W})$ integrated with an air duct. Two DC fans $(12 \mathrm{~V})$ blow air into air duct. Fig. 4 shows the front view of PV/T air collector setup and its components.

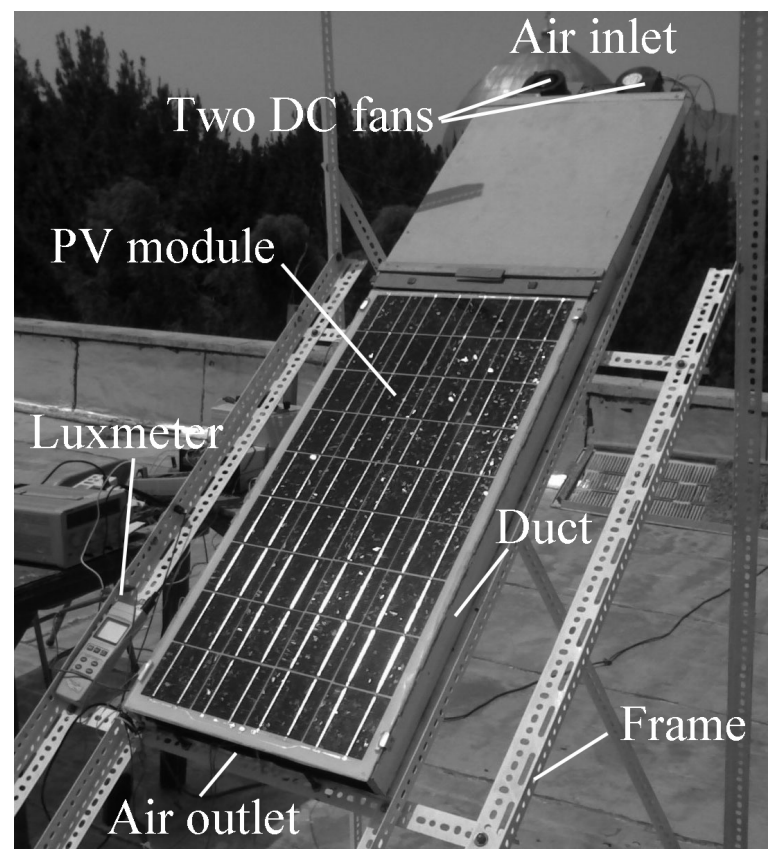

Fig. 4. Photograph of experimental setup of hybrid PV/T air collector

The experiments have been carried out on the constructed PV/T air collector in the Department of Mechanical Engineering, University of Sistan \& Baluchestan, Zahedan (Iran), which is located at $60^{\circ}: 54^{\prime} \mathrm{E}$ longitude and $29^{\circ}: 32^{\prime} \mathrm{N}$ latitude. The measurements were recorded on a clear day from 9:00 a.m. to 5:00 p.m. in July 2011 with experimental data being recorded every 30 minutes. The measured data include the solar radiation intensity, ambient temperature, inlet and outlet air temperature, solar cell temperature, inlet air velocity, wind speed, opencircuit voltage, short-circuit current, maximum power point current and maximum power point voltage.

Solar radiation intensity was measured by a Digital Lux-meter (LX-1108) at the same incident plane of the PV module. Fifteen temperature sensors (DS18B20 ( $\times 8)$, DS1620 (x7)) were used to measure temperatures at a different location in the PV module and air duct. Wind speed was measured $30 \mathrm{~cm}$ above the PV modules by a Lutron Digital Anemometer (LM-8000). Two Digital Multimeter (Victor) were been used to measure various currents $\left(I_{s c}, I_{m p}\right)$ and voltages $\left(V_{o c}, V_{m p}\right)$. Another Lutron Digital Anemometer (LM-8000) was used to measure air flow while entering the air duct.

The design parameters of the $P V / T$ air collector are described in Table 1.

Table 1. The design parameters of the PV/T air collector

\begin{tabular}{cc}
\hline Parameter & Value \\
\hline PV Module & Polycrystalline silicon $45 \mathrm{~W}$ \\
\hline$L \times W \times \delta$ & $0.997 \mathrm{~m} \times 0.462 \mathrm{~m} \times 0.05 \mathrm{~m}$ \\
\hline$I_{s c, \text { ref }}$ & $2.98 \mathrm{~A}$ \\
\hline$V_{\text {oc,ref }}$ & $20.5 \mathrm{~V}$ \\
\hline$I_{\text {mp,ref }}$ & $2.76 \mathrm{~A}$ \\
\hline$V_{\text {mp,ref }}$ & $16.3 \mathrm{~V}$ \\
\hline$\alpha$ & $5.6 \mathrm{~mA} /{ }^{\circ} \mathrm{C}$ \\
\hline$\beta$ & $-0.12 \mathrm{~V} /{ }^{\circ} \mathrm{C}$ \\
\hline$\beta_{\text {cell }}$ & 0.8 \\
\hline$V_{\text {in, exp }}$ & $3 \mathrm{~m} / \mathrm{s}$ \\
\hline
\end{tabular}

The simulated values of outlet air temperature, solar cell temperature, open-circuit voltage, shortcircuit current, maximum power point voltage and maximum power point current validated by their corresponding experimental values. Furthermore, a comparison between the experimental and simulated values of thermal efficiency and electrical efficiency were carried out.

In order to compare the simulated results with the experimental measurements, a root mean square percentage deviation (RMS) was evaluated by following equation [5] to [9]:

$$
R M S=\sqrt{\sum\left[100 \times\left(X_{\text {sim }, i}-X_{\text {exp }, i}\right) / X_{\text {exp }, i}\right]^{2} / n},
$$

where $n$ is the number of the experiments carried out. The inlet air velocity was kept in a constant value during the course of experiments $\left(V_{\text {in,exp }} \approx 3 \mathrm{~m} / \mathrm{s}\right)$. The variations of solar radiation intensity, and wind speed during the test day are shown in Fig. 5.

The experimental and simulated values of various temperatures (solar cell temperature, outlet air temperature, inlet air temperature, ambient temperature) during the test day are shown in Fig. 6. According to this figure, it has been observed that there is a good agreement between the experimental and simulated values of the mentioned temperatures. 
Furthermore, the root mean square percentage deviations of these temperatures are 4.75 and 3.69\%, respectively.

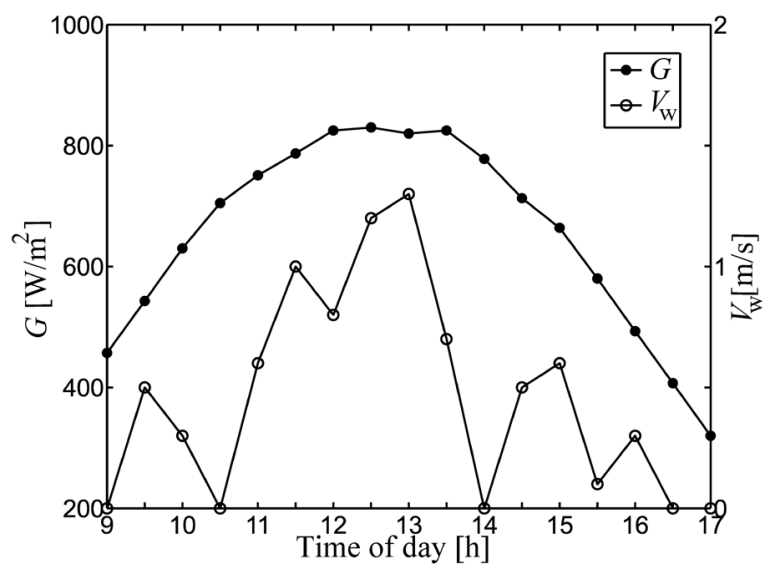

Fig. 5. The variations of solar radiation intensity and wind speed during the test day

The experimental and simulated values of opencircuit voltage, maximum power point voltage, shortcircuit current and maximum power point current during the test day are shown in Fig. 7. A comparison between the experimental and simulated values of these parameters are carried out in this figure. The root mean square percentage deviations of these parameters are $3.66,4.24,7.75$, and $7.23 \%$, respectively.

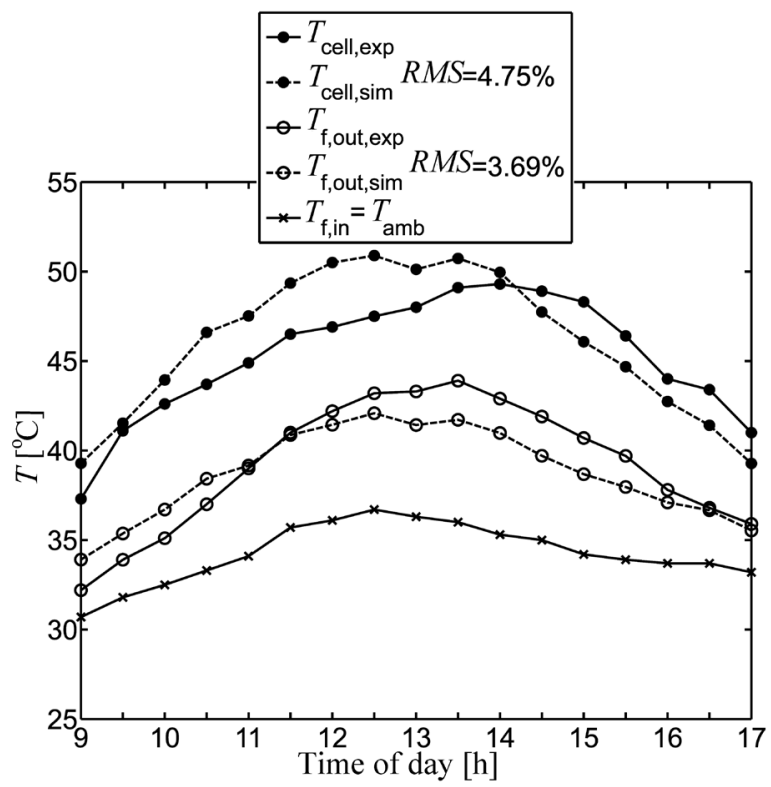

Fig. 6. The experimental and simulated values of the various temperatures of PV/T air collector during the test day
The experimental and simulated values of thermal efficiency and electrical efficiency on the test day are shown in Fig. 8.

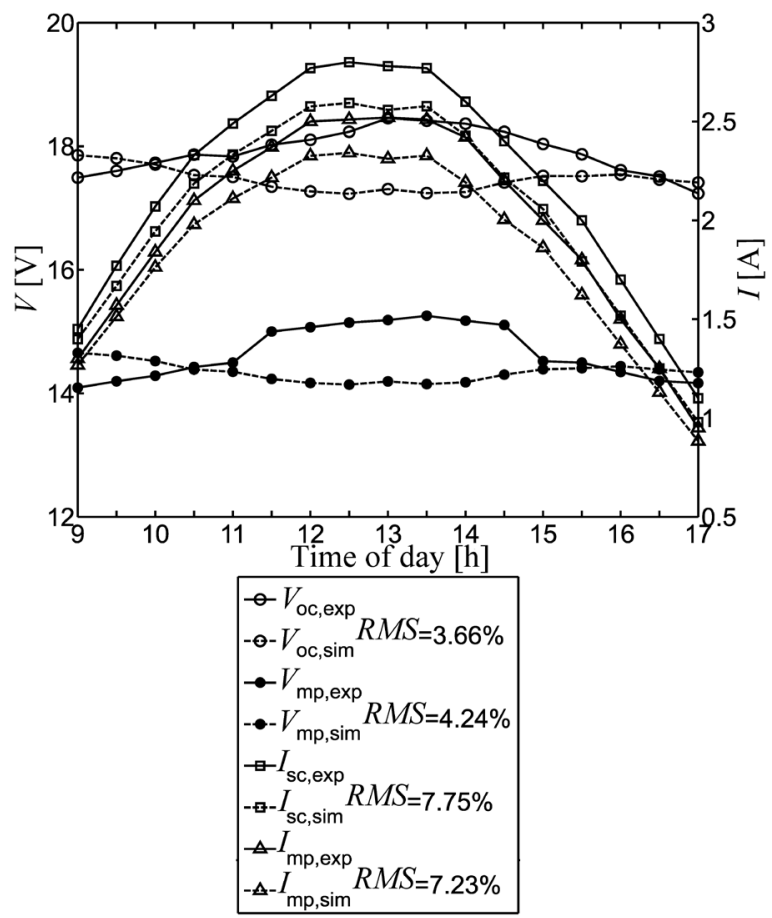

Fig. 7. The experimental and simulated values of various voltage and current during the test day

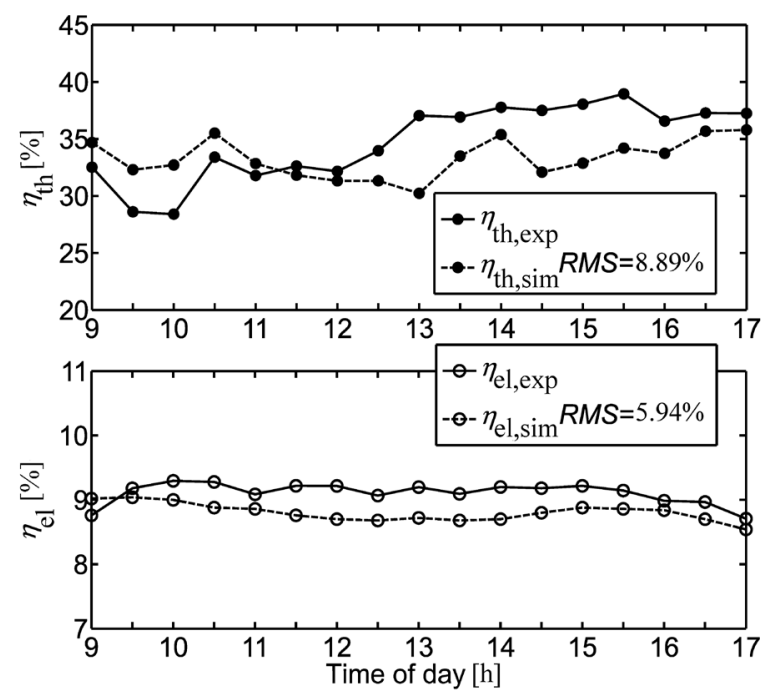

Fig. 8. The experimental and simulated values of thermal efficiency and electrical efficiency

According to this figure, it has been observed that there is a good agreement between the experimental and simulated values of these efficiencies. Furthermore, the root mean square percentage 
deviations of these efficiencies are 8.89 and $5.94 \%$, respectively.

The simulated parameters errors compared with those obtained by the experimental measurement are explained as follows:

- temperature coefficients of current and voltage have been assumed constant. In practical cases, there is slight fluctuation due to the solar radiation intensity and PV module temperature variations;

- radiative properties of absorbing surface has been assumed constant while they are changing during the day with the change of solar incidence angle on $\mathrm{PV} / \mathrm{T}$ collector surface.

\section{OPTIMIZATION RESULTS AND PARAMETRIC STUDIES}

Fig. 9 shows the values of objective functions and decision variables in optimal Pareto front.
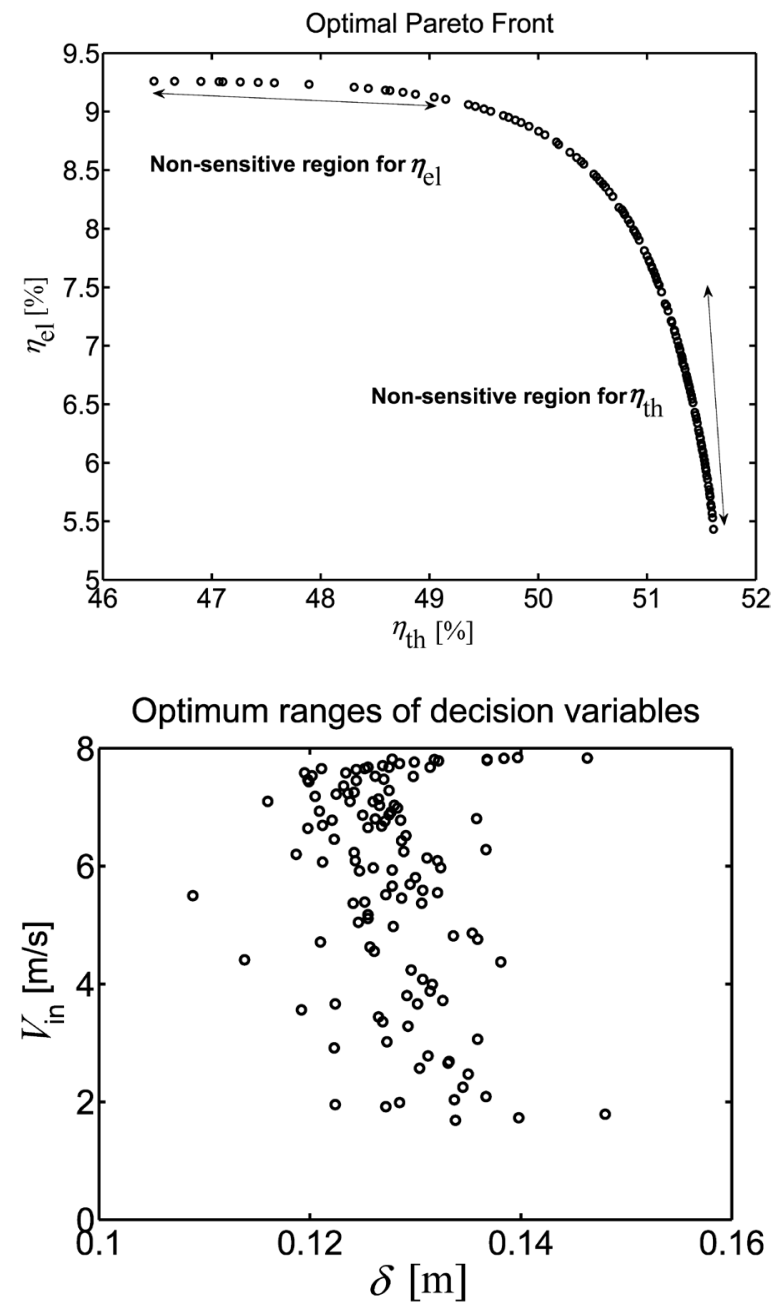

Fig. 9. The optimum values of objective functions and decision variables in optimal Pareto front
The numerical range of the points shown in Fig. 9 is given in Table 2. The non-sensitive regions of the thermal efficiency and the electrical efficiency are also indicated in the same figure.

Table 2. The results of simultaneous optimization

\begin{tabular}{cc}
\hline $\begin{array}{c}\text { Optimum range } \\
\text { of decision variables }\end{array}$ & $\begin{array}{c}\text { Optimum range } \\
\text { of objective function }\end{array}$ \\
\hline $0.109 \leq \delta \leq 0.148$ & $46.46 \leq \eta_{\text {th }} \leq 51.61 \%$ \\
\hline $1.68 \leq V_{\text {in }} \leq 7.74 \mathrm{~m} / \mathrm{s}$ & $5.43 \leq \eta_{e l} \leq 9.26 \%$ \\
\hline
\end{tabular}

Unlike the conventional multi-objective optimization algorithms, the NSAG-II algorithm gives a range for each decision variables. In optimal Pareto front all the points have the same condition. Each point shown in Fig. 9, introduces a vector of decision variables, $\vec{X}\left(\delta, V_{i n}\right)$. In other words, each decision variable can not be selected solely; designer should choose a vector of decision variables. It is clear from Fig. 9 that choosing appropriate values for the decision variables, namely duct depth $(\delta)$ and inlet air velocity $\left(V_{i n}\right)$, to obtain a better value of one objective would normally cause a worse value of another objective. This subject shows Pareto optimal conditions. A designer can choose the desired vector of decision variables among optimal Pareto solutions according to their considerations such as thermal or electrical point of view, design limitations, economic costs, etc.

According to the results obtained from simultaneous optimization (Fig. 9), the thermal efficiency can be increased from $\sim 46.5$ to $\sim 49 \%$, while the electrical efficiency remains constant $(\sim 9.3 \%)$, approximately. On the other hand, the electrical efficiency can be increased from $\sim 5.5$ to $\sim 7.5 \%$, while the thermal efficiency has no sensible variations $(\sim 51.5 \%)$. This subject is suitable from engineering design perspective as it leads to nonsensitive selection from a thermal or electrical point of view.

In order to plot the following figures some parameters are assumed which are mentioned above each figure. Fig. 10 shows the variations of thermal efficiency and electrical efficiency with respect to inlet air velocity.

The thermal efficiency increases from 0 to $\sim 52 \%$ while inlet air velocity is increasing from 0.001 to $12 \mathrm{~m} / \mathrm{s}$. On the other hand, the electrical efficiency decreases from $\sim 9$ to $0 \%$ while inlet air velocity is increasing. The increase of inlet air velocity increases pressure drop in air duct, therefore the consumed power by fans is raised and in consequence, the electrical efficiency decreases. 


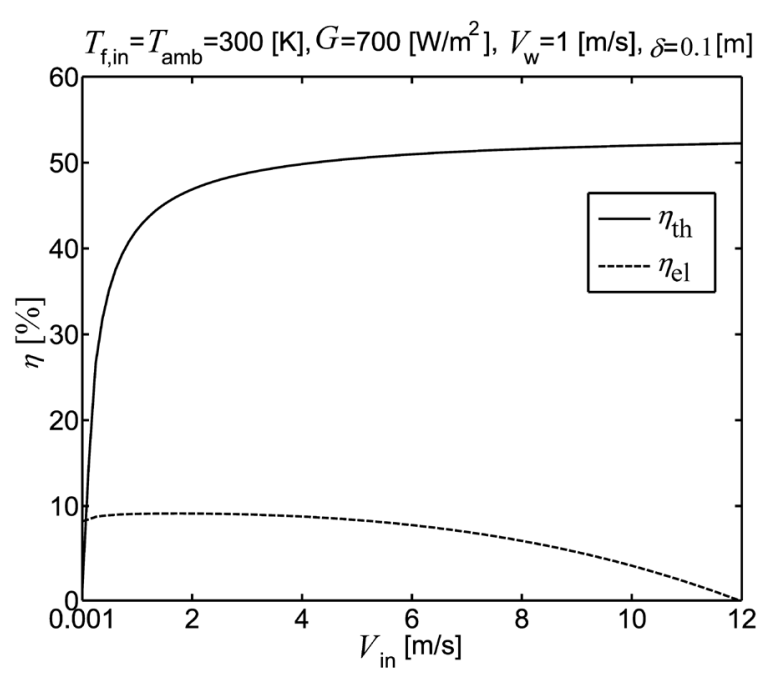

Fig. 10. The variations of thermal efficiency and electrical efficiency with respect to inlet air velocity

The variations of thermal efficiency and electrical efficiency with respect to duct depth are shown in Fig. 11.

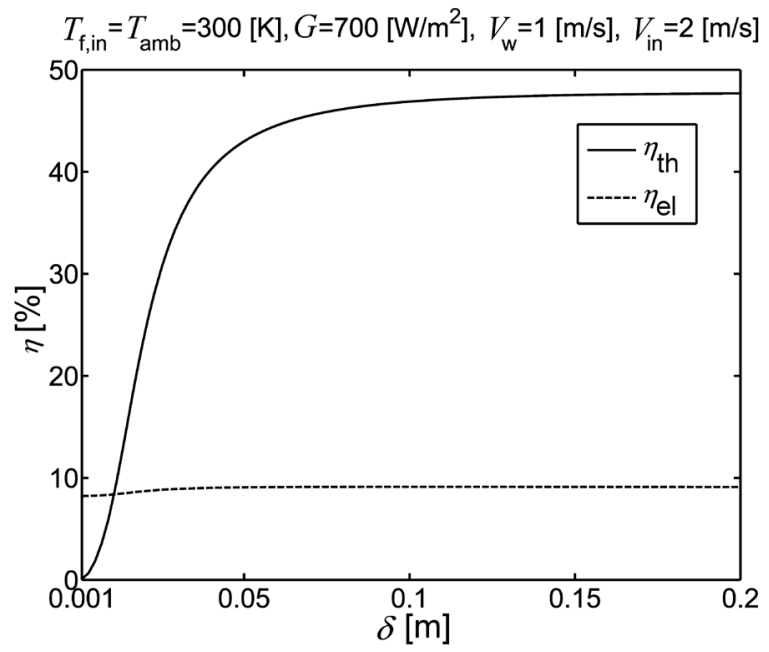

Fig. 11. The variations of thermal efficiency and electrical efficiency with respect to duct depth

According to this figure, the thermal efficiency increases from 0 to $\sim 48 \%$ when duct depth increases from 0.001 to $0.2 \mathrm{~m}$. On the other hand, the electrical efficiency has a slight change with respect to duct depth $(\sim 8 \%)$.

Fig. 12 shows the effect of solar radiation intensity on the thermal efficiency and electrical efficiency. It has been observed that the electrical efficiency increases from 0 to $\sim 8 \%$ initially and then it remains constant after the solar radiation intensity reaches about $200 \mathrm{~W} / \mathrm{m}^{2}$. This indicates the optimum value of solar radiation intensity for given climatic and design parameters (Table 1). On the other hand, thermal efficiency has a slight change ( 52\%) with respect to solar radiation intensity variations.

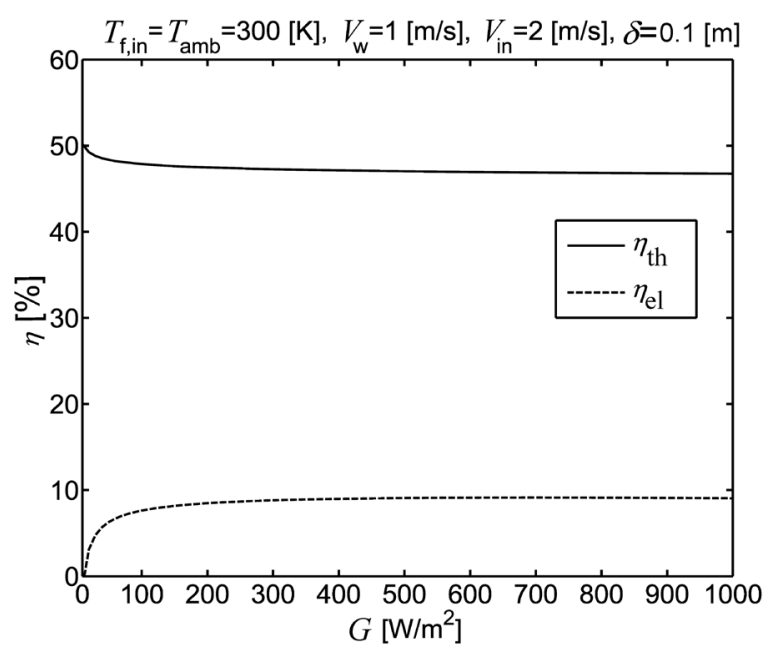

Fig. 12. The effect of solar radiation intensity on the thermal efficiency and electrical efficiency

Fig. 13 shows the variations of thermal efficiency and electrical efficiency according to the changes of wind speed.

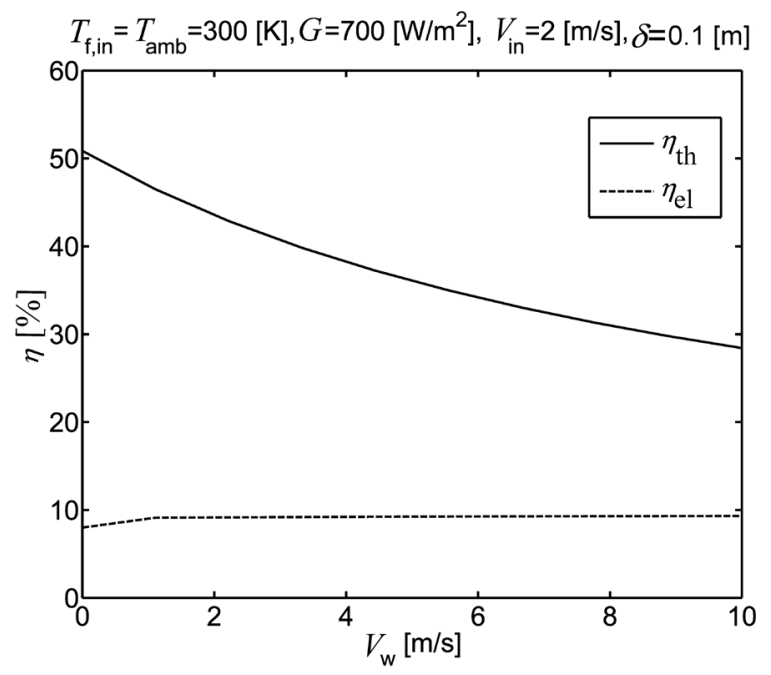

Fig. 13. The variations of thermal efficiency and electrical efficiency with respect to wind speed

Acoording to Fig. 13, thermal efficiency decreases from $\sim 51$ to $\sim 29 \%$ while wind speed increases from 0 to $10 \mathrm{~m} / \mathrm{s}$. On the other hand, electrical efficiency increases from $\sim 8$ to $\sim 9.5 \%$ while wind speed is increasing. The increase of wind speed increases overall heat loss coefficient, therefore solar 
cell temperature is decreased and in consequence, the thermal efficiency decreases and the electrical efficiency increases.

\section{CONCLUSION}

On the basis of the present study, the following conclusions have been drawn:

- The numerical simulation results are in good agreement with the experimental measurements carried out;

- Unlike the conventional optimization methods, the simultaneous optimization by NSAGII algorithm gives a range for each decision variables;

- The thermal efficiency can be increased from $\sim 46.5$ to $\sim 49 \%$, while electrical efficiency remains constant ( $\sim 9.3 \%)$, approximately. On the other hand, electrical efficiency can be increased from $\sim 5.5$ to $\sim 7.5 \%$, while the thermal efficiency has not sensible variations ( $\sim 51.5 \%)$. This subject is desired from a perspective of engineering design as a designer can choose the desired vector of decision variables among optimal Pareto solutions according to their considerations such as thermal or electrical application, design limitations, economic costs, etc.;

- Increasing the solar radiation intensity, the electrical efficiency of $\mathrm{PV} / \mathrm{T}$ air collector increases initially and then it remains constant after attaining solar radiation intensity of about a maximum point.

\section{NOMENCLATURE}

$a$ ideality factor $[\mathrm{eV}]$

$A$ area $\left[\mathrm{m}^{2}\right]$

$C_{\mathrm{p}}$ specific heat capacity of air $[\mathrm{J} /(\mathrm{kg} \cdot \mathrm{K})]$

$G$ solar radiation intensity $\left[\mathrm{W} / \mathrm{m}^{2}\right]$

$h$ heat transfer coefficient $\left[\mathrm{W} /\left(\mathrm{m}^{2} \cdot \mathrm{K}\right)\right]$

$h_{\mathrm{p}}$ penalty factor

$I$ current [A]

$L \quad$ dimensions of $\mathrm{PV} / \mathrm{T}$ air collector $[\mathrm{m}]$

$\dot{m}$ mass flow rate of air $[\mathrm{kg} / \mathrm{s}]$

$P \quad$ power [W]

$T$ temperature $[\mathrm{K}]$

$U$ overall heat loss coefficient $\left[\mathrm{W} /\left(\mathrm{m}^{2} \cdot \mathrm{K}\right)\right]$

$V$ circuit voltage [V], wind speed $[\mathrm{m} / \mathrm{s}]$

$W$ width of $\mathrm{PV} / \mathrm{T}$ air collector [m]

Greek symbols

$\alpha \quad$ current temperature coefficient $\left[\mathrm{mA} /{ }^{\circ} \mathrm{C}\right]$ $\beta$ packing factor, voltage temperature coefficient $\left[\mathrm{V} /{ }^{\circ} \mathrm{C}\right]$

$\delta \quad$ duct depth [m]

$\eta \quad$ efficiency [\%]

$\rho$ density $\left[\mathrm{kg} / \mathrm{m}^{3}\right]$

\section{Subscripts}

ambambient

bs back surface of tedlar

cell cell, module

el electrical

exp experimental

$f$ fluid flow

fan fan

in inlet

$L \quad$ light current

$m p$ maximum power point

$o$ reverse saturation

$o c$ open-circuit

out outlet

$P V / T \mathrm{PV} / \mathrm{T}$

ref reference

$s$ series

sc short-circuit

sh shunt

sim simulated

th thermal

$u$ useful

$w$ wind

\section{REFERENCES}

[1] Wolf, M. (1976). Performance analysis of combined heating and photovoltaic power systems for residences. Energy Conversion and Management, vol. 16, p. 79-90, DOI:10.1016/0013-7480(76)90018-8.

[2] Bhargava, A.K., Garg, H.P., Agarwall, R.K. (1991). Study of a hybrid solar system-solar air heater combined with solar cells. Energy Conversion and Management, vol. 31, no. 5, p. 471-479, DOI:10.1016/01968904(91)90028-H.

[3] Hegazy, A.A. (2000). Comparative study of the performances of four photovoltaic/thermal solar air collectors. Energy Conversion and Management, vol. 41, p. 861-881, DOI:10.1016/S0196-8904(99)00136-3.

[4] Infield, D., Mei, L., Eicker, U. (2004). Thermal performance estimation of ventilated PV facades. Solar Energy, vol. 76, p. 93-98, DOI:10.1016/j. solener.2003.08.010.

[5] Tiwari, A., Sodha, M.S., Chandra, A., Joshi, J.C. (2006). Performance evaluation of photovoltaic thermal solar air collector for composite climate of India. Solar Energy Materials \& Solar Cells, vol. 90, no. 2, p. 175-189, DOI:10.1016/j.solmat.2005.03.002. 
[6] Dubey, S., Sandhu, G.S., Tiwari, G.N. (2009). Analytical expression for electrical efficiency of PV/T hybrid air collector. Applied Energy, vol. 86, no. 5, p. 697-705, DOI:10.1016/j.apenergy.2008.09.003.

[7] Joshi, A.S., Tiwari, A., Tiwari, G.N., Dincer, I. (2009). Performance evaluation of a hybrid photovoltaic thermal (PV/T) (glass-to-glass) system. International Journal of Thermal Sciences, vol. 48, p. 154-164, DOI:10.1016/j.ijthermalsci.2008.05.001.

[8] Gaur, M.K., Tiwari G.N. (2010). Optimization of number of collectors for integrated PV/T hybrid active solar still. Applied Energy, vol. 87, p. 1763-1772, DOI:10.1016/j.apenergy.2009.10.019.

[9] Agrawal, B., Tiwari, G.N. (2010). Optimizing the energy and exergy of building integrated photovoltaic thermal (BIPVT) systems under cold climatic conditions. Applied Energy, vol. 87, p. 417-426, DOI:10.1016/j.apenergy.2009.06.011.

[10] Sarhaddi, F., Farahat, S., Ajam, H., Behzadmehr, A. (2010). Exergetic performance evaluation of a solar photovoltaic (PV) array. Australian Journal of Basic and Applied Sciences, vol. 4, no. 3, p. 502-519.

[11] Sarhaddi, F., Farahat, S., Ajam, H., Behzadmehr, A. (2010). Exergy efficiency of a solar photovoltaic array based on exergy destructions. Proceedings of the Institution of Mechanical Engineers, Part A: Journal of Power and Energy, vol. 224, no. 6, p. 813-825, DOI:10.1243/09576509JPE890.

[12] Kim, J.P., Lim, H., Song, J.H., Chang, Y.J., Jeon, C.H. (2011). Numerical analysis on the thermal characteristics of photovoltaic module with ambient temperature variation. Solar Energy Materials \& Solar Cells, vol. 95, p. 404-407, DOI:10.1016/j. solmat.2010.05.016.

[13] Agrawal, S., Tiwari, G.N. (2011). Energy and exergy analysis of hybrid micro-channel photovoltaic thermal module. Solar Energy, vol. 85, no. 2, p. 356-370, DOI:10.1016/j.solener.2010.11.013.

[14] De Soto, W. (2004). Improvement and validation of a model for photovoltaic array performance. M.Sc thesis, University of Wisconsin-Madison, p. 20-74.

[15] Kakaç, S., Liu, H. (2003). Heat exchangers: selection, rating and thermal design. $2^{\text {nd }}$ ed., CRC Press Florida.

[16] Deb, K. (2001). Multi-objective optimization using evolutionary algorithms, $1^{\text {st }}$ ed., John Wiley \& Sons Ltd., Chichester. 